\title{
NEUTRALIZANDO 0 ARGUMENTO DA QUALIDADE: RESULTADOS PRELIMINARES DE UM ESTUDO DE FILOSOFIA EXPERIMENTAL
}

\author{
MuriloSeabra $^{1}$ \\ Laura Tolton ${ }^{2}$ \\ Luke Prendergast ${ }^{3}$
}

RESUMO: Esse artigo explora a hipótese da existência de preconceito de nacionalidade entre os membros da comunidade filosófica brasileira. Por utilizar um experimento para investigar o campo da filosofia, o estudo apresentado aqui pode ser classificado como um estudo de filosofia experimental. Entretanto, ele usa uma metodologia da psicologia cognitiva e tem como backgrounds teóricos as filosofias pós-coloniais e pós-modernas. Pós-graduandos e professores de sete departamentos de filosofia brasileiros avaliaram textos atribuídos a autores europeus e latinoamericanos. A análise dos resultados revelou uma preferência pelo autor francês em detrimento do autor brasileiro; entretanto, os resultados foram inconclusivos quando outras nacionalidades latino-americanas foram contrastadas com nacionalidades europeias. Esse estudo indica que a comunidade brasileira de filosofia tende a criticar excessivamente os brasileiros que produzem filosofias próprias ao invés de se limitarem a comentar textos produzidos por autores europeus ou norte-americanos. 
NEUTRALIZANDO 0 ARGUMENTO DA QUALIDADE: RESULTADOS PRELIMINARES...

PALAVRAS-CHAVE: Filosofia Experimental; Preferências Implícitas; Filosofia no Brasil.

ABSTRACT: This paper explores the hypothesis that nationality bias may be present in the discipline of philosophy in Brazil. As it uses an experiment to investigate within the field of philosophy, this study can be said to be part of experimental philosophy. However, it uses methodology from cognitive psychology and theoretical background from postcolonial and postmodern philosophy. Postgraduates and lecturers from philosophy departments at seven Brazilian universities evaluated texts attributed to authors of European and Latin American nationalities. Analysisof the results revealed a preference for the French author over the Brazilian author; however, results were inconclusive when other Latin American nationalities were contrasted with European nationalities. This study indicates that the Brazilian philosophy community is overcritical of Brazilians who produce philosophy of their own, rather than limiting themselves to the commentary of texts produced by European or North American authors.

KEYWORDS: Experimental Philosophy; Implicit Bias; Philosophy in Brazil. 
"A minha família tem feito essa modalidade de luta no Brasil há mais de 75 anos. No Brasil, ninguém a conhecia. Quando ela veio para os Estados Unidos, espalhou-se pelo mundo inteiro."

Royce Gracie

"Os europeus nunca duvidaram de que os índios tinham corpos - os animais também os têm - e os índios, por sua vez, nunca duvidaram de que os europeus tinham almas, uma vez que os animais e os espíritos dos mortos também os têm. Assim, o etnocentrismo dos europeus consistiu em duvidar que os corpos dos outros continham almas formalmente semelhantes àquelas que habitavam os seus próprios corpos, e o dos índios, ao contrário, implicava em duvidar que as almas ou espíritos dos outros podiam possuir corpos materialmente semelhantes aos seus."

Viveiros de Castro ${ }^{5}$

O presente estudo se insere em pelo menos quatro tradições intelectuais distintas: a psicologia cognitiva, que há décadas se dedica ao estudo de preferência simplícitas (que poderíamos também chamar de preconceitos inconscientes), desenvolvendo uma série de métodos extremamente engenhosos para detectálos (GAWRONSKI \& PAYNE, 2010); a filosofia experimental, que reconhece explicitamente a relevância de pesquisas empíricas e análises estatísticas para a filosofia, e que tem atraído nos últimos anos uma avalanche de simpatizantes 
NEUTRALIZANDO 0 ARGUMENTO DA QUALIDADE: RESULTADOS PRELIMINARES...

(LOMBROZO, KNOBE \& NICHOLS, 2014; para uma história da filosofia experimental, ver MURPHY, 2014); a filosofia pós-colonial, de matriz latino-americana, já firmemente consolidada no cenário acadêmico internacional, e que coloca em xeque a narrativa heroica da modernidade europeia (MIGNOLO, 2009, 2011a, 2011b; GROSFOGUEL, 2013); e, finalmente, a filosofia pós-moderna, que tem o mérito de ter chamado a atenção para relações de poder dispersas em todo o tecido social (FOUCAULT, 1979; PIMENTEL, 2016). Embora não tenha deliberadamente tentado superar a divisão entre filosofia analítica e filosofia continental, a presente pesquisa, como deverá ficar mais claro nas páginas seguintes, acabou por se desenvolver de forma a tornar essa divisão pouco útil e bastante suspeita. A filosofia analítica tem limites. A filosofia pós-moderna tem limites. A filosofia acadêmica como um todo tem limites que precisam ser investigados e criticados ao invés de defendidos e reverenciados.

Evidentemente, um grande número de autores que têm questionado o mainstream filosófico também poderia ser mencionado aqui, desde Odera Oruka, que na década de 1970 lançou um programa de pesquisa interessantíssimo sobre filósofos de grande profundidade intelectual, mas sem formação universitária (ORUKA, 1990a, 1990b, 1991; PRESBEY, 2007), até Sally Haslanger, que em 2008 publicou um estudo mostrando que a porcentagem de artigos publicados por mulheres nos maiores jornais de filosofia internacionais não refletia de forma adequada a porcentagem de mulheres trabalhando nos departamentos de filosofia dos Estados Unidos (HASLANGER, 2008; ver também WUENSCH, 2015). 
Existem ainda dois grupos de autores que não constituem propriamente tradições de pensamento, mas que precisam necessariamente ser citados. O primeiro começou a publicar apenas recentemente e é possível que atraia muitos seguidores. Os dois volumes da obra Implicit bias and philosophy, lançados em meados de 2016, contêm o que talvez seja o primeiro esforço de fôlego para extrair as implicações filosóficas das pesquisas sobre preferências implícitas (BROWNSTEIN \& SAUL, 2016a, 2016b). O segundo se constitui de um grupo relativamente pequeno de pensadores extraordinariamente produtivos que tem chamado a atenção para o fato de que a comunidade filosófica brasileira nutre contra si mesma uma hostilidade difícil de se justificar. Possivelmente, os autores mais conhecidos desse grupo sejam Oswaldo Porchat Pereira (2010), Gonzalo Armijos Palacios (2004, 2008), Julio Cabrera (2010, 2015a, 2015b) e Paulo Margutti (2014a, 2014b). Contudo, nenhum desses autores desenvolveu suas reflexões beneficiando-se das tradições de pensamento anteriormente listadas. Pelo contrário, eles se serviram essencialmente de suas próprias forças reflexivas, o que se nota pelo fato de que em suas análises são recorrentes as referências a situações que viveram ou presenciaram como membros da comunidade filosófica brasileira. Não obstante, de forma totalmente independente, eles chegaram a conclusões extraordinariamente parecidas e suficientemente desalentadoras para não poderem ser ignoradas. ${ }^{6}$

É importante mencionar também que a maior parte da comunidade filosófica brasileira não se vê como uma comunidade que nutre hostilidade contra si mesma. A posição hegemônica é que as reflexões de autores como Porchat, 
Armijos, Cabrera e Marguttisão inteiramente descabidas. Não é por causa de uma suposta hostilidade contra a filosofia brasileira que ela não tem um espaço garantido nos cursos de filosofia brasileiros. Pelo contrário, é por não haver uma filosofia brasileira - ou uma filosofia brasileira digna de atenção - que ela não tem um espaço garantido nos cursos de filosofia brasileiros. Os membros da comunidade filosófica brasileira não excluem os autores brasileiros do seu universo de leituras por causa de uma suposta hostilidade contra eles. São os autores brasileiros que excluem a si mesmos por sua falta de qualidade.

\begin{tabular}{|c|c|c|c|}
\hline \multicolumn{2}{|c|}{ Teses de doutorado em filosofia defendidas na USP com nomes de } & Quantidade & Porcentagens \\
\hline \multirow{2}{*}{ autores europeus ou norte-americanos } & nos titulos & 21 & $75 \%$ \\
\cline { 2 - 4 } & nos títulos dos capitulos & 28 & $100 \%$ \\
\hline \multirow{2}{*}{$\begin{array}{c}\text { autores latino-americanos (incluindo } \\
\text { brasileiros), africanos ou asiáticos }\end{array}$} & nos títulos & 0 & $0 \%$ \\
\cline { 2 - 5 } & nos títulos dos capitulos & 0 & $0 \%$ \\
\hline
\end{tabular}

Tabela 1: Nomes de autores europeus, norte-americanos, africanos e asiáticos nos títulos e nos títulos dos capítulos das teses de doutorado em filosofia defendidas na Universidade de São Paulo (USP) no ano de 2015.

Os críticos de Porchat, Armijos, Cabrera e Margutti não têm nenhuma objeção a fazer contra a observação trivial de que os filósofos brasileiros, via de regra, não são estudados nos 
departamentos de filosofia. Por exemplo, um total de 34 teses de doutorado em filosofia foram defendidas na Universidade de São Paulo (USP) no ano de 2015. Se excluirmos as teses dedicadas a autores antigos e medievais, veremos que $75 \%$ contêm nomes de autores europeus ou norte-americanos já em seus títulos. ${ }^{7}$ Quando analisamos os títulos dos capítulos, a porcentagem sobe para $100 \% .{ }^{8}$ É bastante improvável que uma análise das teses de doutorado, dissertações de mestrado e monografias de graduação escritas nos últimos dez anos resulte em proporções significativamente diferentes. E como a USP serve de modelo para um grande número de universidades brasileiras, não seria de se estranhar se proporções semelhantes fossem encontradas em todo o território nacional, especialmente na região sudeste. Um levantamento anterior realizado na Universidade de Brasília (UnB) indicou proporções um pouco menos desalentadoras, mas igualmente preocupantes (SEABRA, 2014).

As dificuldades começam a aparecer quando sepassa à tarefa de identificar os motivos pelos quais os filósofos brasileiros não são lidos pela comunidade filosófica brasileira. É possível que eles não sejam lidos por serem discriminados. Mas é também possível que eles não sejam lidos simplesmente por sua falta de qualidade. Deixando de lado o estranho malabarismo necessário parase determinar a qualidade de um texto sem sequer lê-lo, as proporções observadas na Tabela 1 não podem ser coerentemente utilizadas como evidência de que os pensadores brasileiros são discriminados. Talvez elas não façam mais do que refletir variações de qualidade. Com efeito, a justificativa da qualidade é tão resiliente que a simples demonstração de que existem pensadores brasileiros 
NEUTRALIZANDO 0 ARGUMENTO DA QUALIDADE: RESULTADOS PRELIMINARES...

não basta para abalá-la. O fato de que eles existem - e de que os pensadores latino-americanos, africanos e asiáticos também existem - coloca em xeque a justificativa da proporcionalidade, segundo a qual, por haver mais pensadores europeus e norte-americanos do que brasileiros, é natural que eles sejam mais lidos e estudados. O problema, porém, é sustentar que os pensadores europeus e norte-americanos são simplesmente mais estudados do que os pensadores brasileiros - e os pensadores latino-americanos, africanos e asiáticos - quando se tem uma proporção de $100 \%$ de teses de doutorado dedicadas a pensadores europeus e norteamericanos. Você não pode dizer que na sua empresa há mais trabalhadores brancos do que negros simplesmente por haver na sociedade como um todo mais brancos do que negros quando, na verdade, não há, na sua empresa, trabalhadores negros. Mas a existência de pensadores brasileiros - e de pensadores latino-americanos, africanos e asiáticos - não afeta o argumento da qualidade.

A posição dominante, de fato, é que não existe nenhum preconceito contra os pensadores brasileiros. O que existe é apenas uma constatação neutra e objetiva de que até hoje o Brasil não conseguiu gerar nenhum filósofo de valor. Os estudantes não são desencorajados a pensar. Pelo contrário, eles são encorajados a escrever trabalhos acadêmicos sérios, isto é, trabalhos sobre os grandes filósofos ocidentais cuja autoridade e valor ninguém sonha em questionar. Trata-se, de fato, do caminho mais seguro para se conseguir sucesso acadêmico. Os professores não querem cercear ou limitar as forças intelectuais dos seus estudantes. Eles só querem educálas para não serem desperdiçadas. Eles só querem canalizá- 
las para que sejam utilizadas de forma séria e competente. É bem mais proveitoso escrever um trabalho exegético sólido sobre Wittgenstein ou Heidegger do que perder tempo com autores brasileiros e com aventuras estéreis (paradoxalmente, eles não veem nada de estéril em se acrescentar mais um item à literatura já vasta sobre Wittgenstein ou Heidegger).

A posição de pensadores como Porchat, Armijos, Cabrera e Margutti é que os membros da comunidade filosófica brasileira não confiam na capacidade intelectual dos seus conterrâneos, atribuindo a eles um papel subalterno na economia do saber. O papel dos brasileiros não é o de gerar ideias filosóficas. Não é o de pensar. O papel dos brasileiros é o de consumir ideias filosóficas. É o de analisá-las, comentálase divulgá-las. Consequentemente, quando um brasileiro, ignorando o seu papel, atreve-se a filosofar - ou seja, a fazer aquilo que é reservado exclusivamente aos norte-americanos e europeus -, ele passa a ser visto tanto como ignorante quanto arrogante. Ao ousar trabalhar em suas próprias intuições, ele comete não apenas um pecado epistêmico. Ele comete também um pecado moral. É recomendável, portanto, evitá-lo como interlocutor tanto por causa das suas falhas de julgamento quanto por causa das suas falhas de caráter. $\mathrm{O}$ pensador brasileiro está condenado à solidão intelectual e ao ostracismo acadêmico:

A insistência exclusiva na leitura e a pouca - ou nenhuma - ênfase na reflexão... tiveram a consequência nefasta de impedir nas novas gerações o aparecimento de filósofos. Formavam-se, e formam-se ainda, eruditos, leitores, comentadores, isto é, professores de filosofia, 
NEUTRALIZANDO 0 ARGUMENTO DA QUALIDADE: RESULTADOS PRELIMINARES...

não filósofos. (...) Que Brasil seria esse no qual um Heitor Villa-Lobos tivesse sido coibido de compor? (ARMIJOS, 2004, p.21)

A pesquisa em História da Filosofia tem sido fortemente desenvolvida entre nós, com profícuos resultados. Um número já impressionante de boas monografias historiográficas foram produzidas por nossos professores e pós-graduados e isso é e deve ser para nós um motivo de orgulho. Estamos fazendo boa História da Filosofia e estamos preparando nossos alunos com seriedade e rigor para serem bons historiadores da Filosofia. Isso não está certamente em questão e creio ser objeto de consenso. (...) Quero interrogar-me aqui, porém, sobre se essa é também a melhor maneira de preparar alguém para a prática da Filosofia, para atender ao anseio original dos que vieram ao curso de Filosofia movidos por outra intenção que não a de tornar-se um dia bons historiadores do pensamento filosófico. Seus impulsos eram filosóficos. Acredito que se pode dizer isso de um bom número de nossos estudantes. E me ocorre, então, a seguinte pergunta, que formularei com alguma brutalidade: estamos contribuindo para a concretização desses impulsos, ou os estamos matando? (PORCHAT, 2010, pp.18-21)

Em virtude disso, continuamos a fazer pesquisas concentradas em um único tema num único autor e as nossas teses de doutorado pecam pela pouca originalidade. (...) É claro que há exceções a esse quadro, mas elas são poucas e o que predomina é a situação descrita, em que o máximo de abertura para a criatividade está na possibilidade de elaborar 
uma interpretação original de um autor clássico. (MARGUTTI, 2014a, p.399)

Em nossos meios acadêmicos, os colegas esboçam um sorriso irônico e autossuficiente quando lhes falamos de pensamento filosófico latino-americano ou, especificamente, de pensamento brasileiro. Para eles, isso não existe. (CABRERA, 2015a, p.5)

Será que os pensadores brasileiros são realmente tratados de forma injusta? Será que eles são olhados de cima para baixo por ousarem colocar os seus próprios pensamentos no papel? Será que eles são discriminados assim como as pessoas que não permanecem obedientemente em seus gêneros e os demais grupos que precisam conviver diariamente com abusos de toda a sorte? Será que eles são punidos por não respeitarem a distribuição internacional do trabalho intelectual, que reserva aos países desenvolvidos a tarefa de produzir teorias e aos países em desenvolvimento a tarefa de aplicá-las e consumi-las? Será que a única maneira de não ser olhado de forma atravessada pelos membros da comunidade filosófica brasileira seja limitando-se a escrever comentários? Ou será que os pretensos pensadores brasileiros são tratados de forma neutra e objetiva? Será que eles não são mencionados pura e simplesmente por não serem dignos de menção? Será que eles não são lidos nos cursos de filosofia por não terem escrito trabalhos suficientemente sérios, originais e interessantes? Será que a comunidade filosófica brasileira está somente agindo como deveria agir, isto é, de forma imparcial,sem se deixar afetar por questões de nacionalidade? Não é possível saber 
NEUTRALIZANDO 0 ARGUMENTO DA QUALIDADE: RESULTADOS PRELIMINARES...

sem antes neutralizar o argumento da qualidade. Apesar do apreço especial da filosofia pelo mundo das ideias, às vezes é preciso levar a luta para o chão.

Com oobjetivo de averiguar a validade das intuições de Porchat, Armijos, Cabrera e Margutti, um questionário desenhado para detectar preferências implícitas - ou preconceitos inconscientes - foi aplicado no primeiro semestre de 2015 em 7 universidades brasileiras. ${ }^{9,}{ }^{10}$ Um total de 93 membros da comunidade filosófica brasileira, dos quais 44 eram professores universitários e 49 pós-graduandos, responderam um questionário consideravelmente longo, de oito páginas. ${ }^{11}$ A primeira página explicava que o objetivo da pesquisa era estudar o comportamento crítico da comunidade filosófica brasileira, mas não que se estava tentando detectar a presença de preconceitos inconscientes. A segunda página continha informações que o subcomitê de ética que autorizou a pesquisa pediu para serem incluídas no questionário, como, por exemplo, que a identidade dos participantes não seria nem poderia ser revelada, porque os questionários tinham que ser respondidos de forma anônima. A terceira página pedia aos participantes que fornecessem detalhes como gênero e ano de nascimento (mas não os seus nomes), que informassem se tinham ou não formação em outra área além da filosofia, e que nomeassem os autores contemporâneos mais recorrentes em suas pesquisas e as suas áreas de maior interesse na filosofia.

A partir das informações fornecidas na terceira página, uma série de variáveis foram criadas para permitir controlar, 
da forma mais rigorosa possível, a influência do background intelectual dos participantes sobre as suas respostas. Por exemplo, uma variável classificou os participantes em filósofos analíticos ou continentais; uma segunda classificouos em analíticos, continentais ou pós-modernos (sendo pós-modernos os participantes que citaram pelo menos um autor pós-moderno entre os filósofos mais recorrentes em suas pesquisas); e uma terceira, em lógicos, epistemólogos, metafísicos, éticos, políticos ou estetas. Foram também criadas variáveis levando em consideração a nacionalidade dos autores citados pelos participantes. Assim, por exemplo, foram identificados todos os participantes que liam pelo menos um autor francês, todos os participantes que liam pelo menos um autor alemão, todos os participantes que liam pelo menos um autor britânico, todos os participantes que liam pelo menos um autor norte-americano, todos os participantes que liam pelo menos um autor oriundo de um país em desenvolvimento etc.

O questionário propriamente dito começava na quarta página. A tarefa dos participantes consistia simplesmente em ler e avaliar três excertos, indicando o seu grau de concordância ou discordância em relação a cinco enunciados avaliativos. Os participantes deveriam também informar se indicariam ou não tanto o Excerto 1 quanto o Excerto 3 para publicação, mas não o Excerto 2. O Excerto 1 consistia em uma crítica à civilização, o Excerto 2 em uma crítica à filosofia analítica e o Excerto 3 em uma crítica à filosofia pós-moderna.

Porém, os questionários não eram absolutamente idênticos. Do total de 93 professores e pós-graduandos que participaram da pesquisa, 53 responderam o questionário $\mathrm{A}$, 
NEUTRALIZANDO 0 ARGUMENTO DA QUALIDADE: RESULTADOS PRELIMINARES...

onde o Excerto 1 era atribuído a um autor europeu, o Excerto 2 a um autor latino-americano, e o Excerto 3 mais uma vez a um autor europeu, e 40 responderam o questionário $\mathrm{B}$, indistinguíveldoquestionário $\mathrm{A}$, mas com a importante diferença de que agora o Excerto 1 era atribuído a um autor latino-americano, o Excerto 2 a um autor europeu, e o Excerto 3 mais uma vez a um autor latino-americano. Isto é, as nacionalidades dos autores eram sistematicamente invertidas. Por exemplo, no questionário A, a autoria do Excerto 1 foi atribuída a Marc Thévenet, nome de caráter marcadamente francês, ao passo que, no questionário $\mathrm{B}$, a autoria do mesmo excertofoi atribuída a Marcos Teixeira, nome que facilmente poderia ser de um brasileiro. Para evitar que o nome Marc Thévenet fosse visto como, por exemplo, marfinense ou senegalês, acrescentou-se que o Excerto 1do questionário A havia sido extraído de uma revista de filosofia francesa. Para evitar que o nome Marcos Teixeira fosse visto como, por exemplo, português ou angolano, acrescentou-se que o Excerto 1 do questionário $\mathrm{B}$ havia sido extraído de uma revista de filosofia brasileira.

\begin{tabular}{|c|c|c|c|}
\hline \multirow{2}{*}{$\begin{array}{c}\text { Estrutura dos } \\
\text { questionánios }\end{array}$} & Nacionalidade dos autores \\
\cline { 2 - 4 } & Excerto 1 & Excerto 2 & Excerto 3 \\
\hline Questionánio A & Francès & Mexicano & Alemão \\
\hline Questionánio B & Brasileiro & Francês & Chileno \\
\hline
\end{tabular}

Tabela 2: Estrutura dos questionários A e B.

O excerto atribuído a um autor europeu no questionário $A$ foi atribuído a um autor latino-americano no questionário $\mathrm{B}$, e vice-versa. 
A respeito dos nomes dos autores criados para assinar os excertos, algumas observações precisam ainda ser feitas. Se a autoria dos excertos tivesse sido atribuída não a Marc Thévenet e Marcos Teixeira, mas a filósofos reais, como, por exemplo, Jean-Paul Sartre e Vicente Ferreira da Silva, uma série de problemas poderia ocorrer. Em primeiro lugar, os excertos poderiam ser lidos contra o pano de fundo de suas filosofias, e não como peças autocontidas e portanto intercambiáveis (o que não ameaçaria a exigência de identidade gráfica dos excertos, mas ameaçaria seriamente a exigência de identidade de sentidos). Em segundo lugar, não seria possível saber os verdadeiros motivos da preferência, caso fosse observada, por um ou por outro autor. Teria sido por causa de suas diferentes nacionalidades? Ou por causa de posturas prévias já tomadas a respeito de suas filosofias? Ou quem sabe por seus diferentes graus de prestígio? O fato de que Marc Thévenet e Marcos Teixeira não existem ajudou a garantirque os participantes avaliassem os excertos servindo-se de um número mínimo de pistas. De fato, não se pode tirar muitas conclusões a partir de seus nomes, a não ser que são ambos homens, que são ambos desconhecidos, possivelmente pensadores iniciantes, e que um é francês e o outro é brasileiro.

Se a autoria do Excerto 1 tivesse sido, no questionário A, atribuída a Marc Thévenet, e, no questionário B, a Márcia Teixeira, e se os resultados tivessem indicado um favorecimento de Marc Thévenet, não seria possível decidir se o favorecimento se deu em função do fator nacionalidade ou em função dofator gênero. Portanto, o gênero dos autores criados para os questionários foi mantido constante. Por fim, se o contraste tivesse sido entre Marc Thévenet e Sebastião 
NEUTRALIZANDO 0 ARGUMENTO DA QUALIDADE: RESULTADOS PRELIMINARES...

ou Severino da Silva, por exemplo, o fato de que os nomes Sebastião e Severino são com frequência utilizados na mídia brasileira para personagens de baixo prestígio poderia interferir no efeito da nacionalidade sobre a percepção de qualidade. Tanto num caso como o outro, os resultados poderiam ser mais fortes. Mas não seria fácil identificar adequadamente os fatores por trás dos efeitos observados.

A hipótese era que os autores europeus seriam sistematicamente favorecidos em detrimento dos autores latino-americanos. Mas não havia nada na arquitetura dos questionários impedindo que os autores latino-americanos fossem favorecidos em detrimento dos autores europeus. Seria possível encontrar, por exemplo, um favorecimento dos autoreslatino-americanos nos Excertos 1, 2 e 3. Ou então nenhum favorecimento, nem dos europeus, nem dos latinoamericanos. Ou então um favorecimento do autor europeu no Excerto 1, um favorecimento do autor latino-americano no Excerto 2, e nenhum favorecimento no Excerto 3.

É importante notar que se os resultados não indicassem nenhum favorecimento dos europeus em detrimento dos latino-americanos, porém, eles não colocariam problemas sérios para a filosofia pós-colonial. Eles não testemunhariam contra a ideia de que vivemos sob uma geopolítica do saber que atribui aos países desenvolvidos a tarefa de ensinar e aos países em desenvolvimento a tarefa de aprender. Eles simplesmente afastariam uma preocupação que deveria ser levada a sério: a de que a divisão internacional do trabalho intelectual pode estar deixando marcas profundas nos membros da comunidade filosófica, afetando sorrateiramente o funcionamento das suas 
estruturas cognitivas e comprometendo significativamente a sua capacidade de realizar até mesmo a mais elementar das atividades, a saber, a atividade de ler. ${ }^{12}$

A análise estatística das avaliações do Excerto 1 indicou um claro favorecimento do autor francês em detrimento do autor brasileiro. Numa escala de -10 a 10 , os participantes deram uma nota média 1,92 pontos mais alta para o autor francês nas primeiras cinco perguntas avaliativas do Excerto 1 do que para o autor brasileiro $(\mathrm{p}=0,035 ; 95 \% \mathrm{IC}=[0,135$; 3,713]). Quando levamos em consideração a disposição dos participantes para recomendar o texto completo para publicação, o favorecimento do autor francês se torna ainda mais forte, independentemente da forma de se agregar os dados. ${ }^{13}$ Para se compreender melhor o significado desse resultado, pode-se visualizar a seguinte situação. Imagine que dois estudantes, um francês e um brasileiro, estejam fazendo uma prova afim de entrar em um programa de pós-graduação ou afim de receber uma bolsa de estudos. Numa escala de 0,0 a 10,0 o estudante francês receberia quase um ponto inteiro a mais do que o estudante brasileiro pelo simples fato de ser francês. Para sermos mais exatos, ele receberia em média 0,96 a mais, podendo, num dia de sorte, receber mais que 0,96, e, num dia de azar, receber menos que 0,96. Por menor que 0,96 possa parecer, o fato é que se trata de um valor que pode claramente fazer a diferença entre ser aprovado ou ser reprovado em uma seleção, bem como entre receber ou não receber uma bolsa de estudos (quanto maior for a concorrência, maior peso terá o aparentemente pequeno 
valor de 0,96). Ao invés de imaginarmos dois estudantes sendo tratados de formas diferentes por terem nacionalidades diferentes, podemos também imaginá-los sendo tratados de formas diferentes por causa das nacionalidades dos autores que pretendem pesquisar.

Rigorosamente falando, porém, o valor de 0,96 indica menos a intensidade do favorecimento do autor francês do que o grau de afiação do instrumento utilizado na coleta de dados. Um questionário mais afiado poderia detectar um efeito maior. Um questionário menos afiado poderia detectar um efeito menor. Ou mesmo nenhum efeito. Como em situações reais múltiplos critérios avaliativos operam simultaneamente, não apenas cinco, é possível que o valor de 0,96 não faça justiça à intensidade da aversão nutrida pela comunidade brasileira de filosofia contra os filósofos brasileiros.

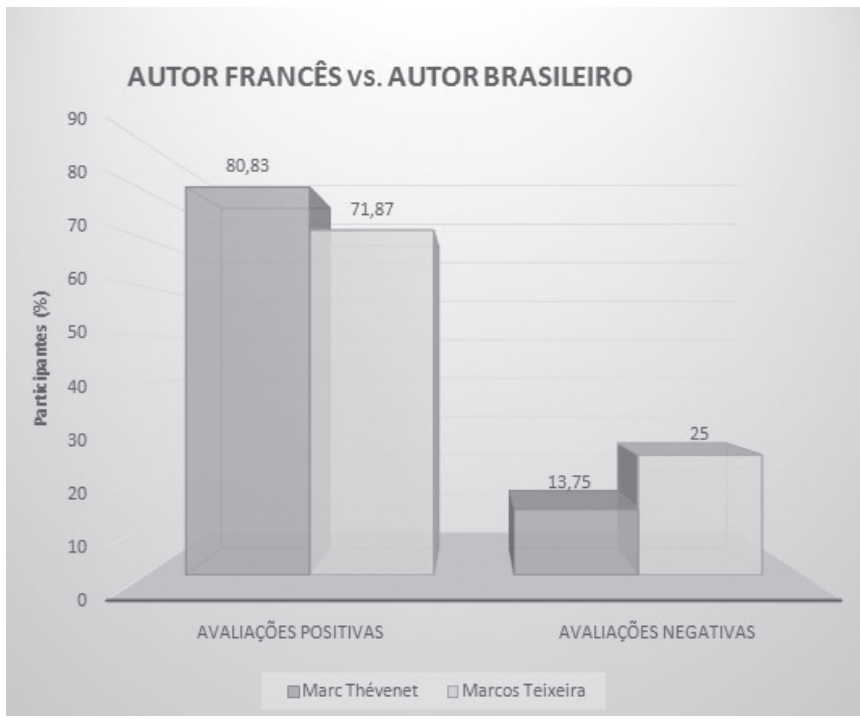

Gráfico1: Influência da nacionalidade do autor sobre a percepção da qualidade do Excerto 1. 
Os Excertos 2 e 3 não revelaram nada de interessante do ponto de vista da hipótese de pesquisa. As análises estatísticas indicaram para ambos os excertos valores-p muito elevados, quando, nas pesquisas envolvendo sujeitos humanos, costuma-se esperar que os valores-p fiquem abaixo de 0,05. ${ }^{14} \mathrm{O}$ valor-p do Excerto 2 foi de 0,177, e o valor-p do Excerto 3 foi de 0,213. No entanto, o Excerto 2, que criticava a filosofia analítica, apresentou um resultado interessante. Os participantes que liam autores continentais e especialmente os que liam autores pós-modernos aprovaram muito mais o Excerto 2 do que os participantes que liam autores analíticos. Numa escala de -10 a 10, os leitores de pós-modernos deram uma nota média 6,5 pontos mais alta $(\mathrm{IC}=[3,363 ; 9,640], \mathrm{p}<$ $0,001)$ e os leitores de continentais 4,0 pontos mais alta para o Excerto 2do que os leitores de analíticos (IC $=[1,022 ; 6,973]$, $p$ $=0,009)$. Evidentemente, não há nada de surpreendente aqui. É de se esperar que os leitores de continentais e especialmente os leitores de pós-modernos julguem um texto que critica a filosofia analítica mais favoravelmente do que os leitores de filósofos analíticos. Porém, trata-se de um resultado que testemunha fortemente a favorda coerência interna dos dados. $^{15,16,17}$

\section{4}

O que significa o fato de que os membrosda comunidade filosófica brasileira apresentaram uma tendência a favorecer o autor europeu na hora de avaliarem o Excerto 1, mas não na hora de avaliarem os Excertos 2 e 3 ? Deveríamos concluir que os membros da comunidade filosófica brasileira nutrem uma 
NEUTRALIZANDO 0 ARGUMENTO DA QUALIDADE: RESULTADOS PRELIMINARES...

desconfiança apenas contra os pensadores brasileiros, mas não contra os pensadores latino-americanos de uma forma mais geral? Afinal, houve uma diferença estatisticamente significativa entre as respostas dadas aos questionários $\mathrm{A} e$ $B$ somente em relação ao Excerto 1 (que contrastava o efeito do nome de um autor brasileiro contra o de um francês), mas não em relação ao Excerto 2 (que contrastava o efeito do nome de um autor francês contra o de um mexicano), nem em relação ao Excerto 3 (que contrastava o efeito do nome de um autor chileno contra o de um alemão). Porém, aquilo que os valores-p extremamente elevados obtidos nos Excertos 2 e 3 indicam não é que se pode afirmar que os membros da comunidade filosófica não tendem a favorecer autores em função de sua nacionalidade; pelo contrário, aquilo que os valores-p extremamente elevados indicam é que não se pode saber se eles tendem ou não a favorecer autores em função de sua nacionalidade. A diferença é grande. Ela equivale à diferença entre dizer"Podemos afirmarque uma luta entre Rickson Gracie e Kazushi Sakuraba teria com certeza terminado em empate" e dizer "Não podemos saber como teria terminado uma luta entre Rickson Gracie e Kazushi Sakuraba, porque as incertezas são muitas". Do ponto de vista da hipótese de pesquisa, é possível extrair conclusões dos resultados obtidos no Excerto 1, mas não dos resultados obtidos nos Excertos 2 e 3. É possível concluir que o autor brasileiro foi desfavorecido em relação ao autor francês. Mas não é possível concluir nem que o autor mexicano foi desfavorecido nem que foi favorecido em relação ao autor francês, e também não é possível concluir nem que o autor chileno foi favorecido nem que foi desfavorecido em relação ao autor alemão. 
Então, o que provocou as diferenças entre os resultados obtidos nos Excertos 1, 2 e 3? Por que apenas o Excerto 1 confirmou a hipótese de pesquisa? É provável que os enunciados avaliando os Excertos 2 e 3 não estivessem suficientemente bem afiados. Mas também é possível que se uma amostra maior de professores e pós-graduandos tivesse respondido o questionário, o preconceito de nacionalidade teria vindo igualmente à tona nas avaliações dos Excertos $2 \mathrm{e}$ 3. Alternativamente, é possível que os participantes, tendo se acostumado visualmente ao questionário, tenham ignorado os cabeçalhos acompanhando os Excertos 2 e 3, julgando-os sobretudo pelo seu teor. A extensão do questionário pode também ter gerado uma progressiva perda de concentração, explicando por uma via diferente porque o Excerto 1 conseguiu captar o fenômeno investigado, mas não os Excertos 2 e 3 . Em todo caso, análises estatísticas preliminares sugeriram queo background intelectual dos participantes exerceu uma influência desproporcional sobre as avaliações dos Excertos 2 e 3, que, ao contrário do Excerto 1, assumiam fortes posições críticas em relação a tradições intelectuais bastante consolidadas entre os membros da comunidade brasileira de filosofia, o Excerto 2 criticando a filosofia analítica e o Excerto 3 criticando a filosofia pós-moderna.

Não deveríamos rechaçar os resultados obtidos no Excerto 1, uma vez que os obtidos nos Excertos 2 e 3 parecem contrariá-los? Em primeiro lugar, como já foi dito antes, embora os dados não permitam concluir que os membros da comunidade filosófica brasileira nutrem um preconceito inconsciente contra os pensadores latino-americanos de forma geral, parece difícil negar que eles nutrem um preconceito 
NEUTRALIZANDO 0 ARGUMENTO DA QUALIDADE: RESULTADOS PRELIMINARES...

inconsciente - e significativo - contra os pensadores brasileiros. Em segundo lugar, também como já foi dito antes, os dados apresentam claras evidências de coerência interna. Se os resultados relativos ao Excerto 2 apontaram na direção esperada com extraordinária precisão (os leitores de pós-modernos e continentais tendem a concordar muito mais com as críticas à filosofia analítica do que os leitores de analíticos), por que deveríamos rechaçar os resultados relativos ao Excerto 1, que também atingiram significância estatística? Os dois excertos foram avaliados pelos mesmos participantes. Se você tem bons motivos para acreditar que eles avaliaram o Excerto 2 de forma sincera, de acordo com o seu modo de pensar, então você tem bons motivos para acreditar que eles também avaliaram o Excerto 1 de forma sincera, de acordo com o seu modo de pensar. Em terceiro lugar, os dados obtidos no Excerto 1 são coerentes com uma vasta e robusta literatura. As pesquisas sobre preferências implícitas - ou preconceitos inconscientes - mostram fartamente que o fenômeno está disperso em todo o tecido social, afetando desde médicos até policiais, desde juízesaté ativistas, desde músicosaté professores universitários. Seria estranho se os membros da comunidade filosófica brasileira fossem imunes a preconceitos inconscientes.

Mas podemos confiar na estatística? O favorecimento do autor francês não pode ter acontecido por acaso? A estatística é justamente um método de controle do acaso. Você não pode descobrir se um dado está viciado jogando-o apenas duas ou três vezes. Imaginemos, porém, que em um total de 100 lances, o número 6 apareça 90 vezes. Se você ainda insistir que não temos razões para dizer que ele está 
viciado, você estará defendendo uma perigosa autonomia dos discursos em relação à textura do mundo, como aquela que se pode observar entre as pessoas que insistem que as mulheres não são tão inteligentes quanto os homens ou que os negros não são tão inteligentes quanto os brancos, apesar de todas as evidências em contrário. Insistir que não temos razões para dizer que um dado está viciado mesmo depois de vermos o número 6 aparecer 90 vezes em um total de 100 lances não é muito diferente de declarar empedernidamente "De acordo com Wittgenstein, os significados das palavras são as imagens mentais dos objetos aos quais elas se referem; por exemplo, o significado da palavra 'vermelho' é a imagem mental do vermelho", quando se sabe que é justamente o contrário que Wittgenstein defende. Quem já encontrou personagens semelhantes pode atestar que a experiência não é das mais agradáveis. É razoável esperar que o comentador de Wittgenstein realmente leia Wittgenstein, e que as suas interpretações de Wittgenstein possam ser colocadas à prova pela leitura dos escritos de Wittgenstein. É razoável esperar que quem fala da realidade ou da sociedade realmente esteja falando algo extraído dela, e que as suas afirmações possam ser colocadas à prova por uma comparação com a realidade ou a sociedade. Não se trata de uma exigência descabida. Da mesma forma, é razoável esperar que aquele que diz "Os membros da comunidade filosófica brasileira não discriminam os pensadores brasileiros" seja capaz de explicar coerentemente o que o faz pensar assim. Não se trata de uma exigência descabida.

Talvez a descoberta de preconceitos inconscientes de gênero ou de raça não causaria tanta surpresa. Os movimentos 
NEUTRALIZANDO 0 ARGUMENTO DA QUALIDADE: RESULTADOS PRELIMINARES...

feminista e negro já conseguiram se estabelecer firmemente no imaginário dos membros da comunidade acadêmica. Mas não há nem pode haver um movimento análogo de pensadores brasileiros, porque eles não são discriminados em todas as esferas da sociedade em função de traços físicos facilmente reconhecíveis. Aliás, pode-se afirmar com bastante certeza que pesquisas semelhantesdesenhadaspara detectar preconceitos de gênero e de raça iriam seguramente detectá-los. Existem evidências de sobra da existência tanto de um quanto do outro (BERNASCONI \& COOK, 2003; DI BELLA, MILES \& SAUL, 2016). O sexismo e o racismo são fenômenosque pulsamcontínua e ininterruptamente sob a superfície da vida acadêmica. O desafio consiste simplesmente em desenvolver instrumentos de pesquisa suficientemente sensíveis para detectá-los. Há muitas maneiras de construi-los de forma a deixar o fenômeno investigado passar entre os dedos. Mas poucas maneiras de construí-los de forma a efetivamente captá-los.

Para se detectar a influência de preferências implícitas ou preconceitos inconscientes na avaliação de trabalhos intelectuais, parece ser importante, por exemplo, usar textos ou excertos capazes de gerar desacordo. Um estudo publicado em 2009 não conseguiu detectar preconceito de gênero entre estudantes de biologia de todos os níveis. Os autores concluíram que provavelmente o preconceito de gênero estivesse diminuindo entre os biólogos (BORSUK et al, 2009). É possível, porém, que o problema tenha sido a utilização de um texto não controverso. De fato, um estudo posterior, de 2012, utilizando não textos idênticos, mas currículos idênticos, detectou preconceito de gênero entre professores de química, 
física e biologia (MOSS-RACUSIN et al, 2012). Sem dúvida, é possível coadunar os dois estudos apontando para o fato de que eles se debruçaram sobre diferentes gerações de biólogos. Porém, talvez haja uma explicação mais plausível para a aparente discrepância: é possível que se espere que tanto homens quanto mulheres sejam capazes escrever trabalhos inexpressivos, mas que apenas homens sejam capazes de escrever trabalhos de ponta.

\section{5}

Mas um estudo que envolve investigações empíricas e análises estatísticas pode ainda ser classificado como um estudo filosófico? Os filósofos estão constantemente usando os seus próprios poderes de observação para falar dos fenômenos à sua volta. As pesquisas empíricas consistem pura e simplesmente em observações controladas e estruturadas. Os métodos mais descontraídos de observação geralmente utilizados pela filosofia e os métodos mais rigorosos utilizados, por exemplo, pela psicologia cognitiva, estão, por assim dizer, em pontos diferentes do mesmo espectro. Portanto, as diferenças entre escrever com base em observações casuais e escrever com base na coleta de dados quantitativos não deveriam ser exageradas. $\mathrm{E}$ as diferenças entre escrever sobre a filosofia de Wittgenstein ou de Heidegger e escrever sobre a realidade circundante também não deveriam ser exageradas. Pois o ato de ler um livro é tão empírico quanto o ato de coletar dados etnográficos ou quantitativos. A diferença entre um retrato casual e um retrato rigorosamente construído da 
NEUTRALIZANDO 0 ARGUMENTO DA QUALIDADE: RESULTADOS PRELIMINARES...

realidade é de grau, não de tipo. Ela equivale simplesmente à diferença entre um resumo escrito às pressas da filosofia de Wittgenstein e um estudo pacientemente documentado da filosofia de Wittgenstein.

Assim como os mitos e as narrativas ficcionais, os textos filosóficos podem geralmente ser divididos em três atos. O primeiro é o momento empírico ou expositivo, onde se coloca as peças no tabuleiro. Ele costuma ser anunciado por expressões como "Geralmente, acredita-se que..." ou "Os filósofos analíticos pensam que.... O segundo é o momento argumentativo, que estilhaça a visão de mundo exposta no primeiro ato. Ele costuma utilizar fartamente expressões como "Mas...", "Porém..." e "Entretanto.... O terceiro, por fim, é o momento propositivo, que apresenta uma nova plataforma de pensamento (e que será talvezreduzido a primeiro momento em uma nova filosofia). Os filósofos não costumam se demorar no momento expositivo (do qual os comentadores geralmente não passam). Mas talvez as diferenças entre aqueles que passam rapidamente ao segundo ato e aqueles que mergulham até as suas profundezas do primeiro ato antes de avançarem sejam apenas diferenças de estilo. Ou de necessidade. Se os seus interlocutores estiverem de acordo com o que você expôs no primeiro ato, você poderá passar rapidamente pelo momento expositivo e concentrar as suas energias nos momentos argumentativo e propositivo. Mas se eles não estiverem de acordo com a sua visão da realidade, talvez seja uma boa ideia substanciar com mais cuidado as suas afirmações antes de passar para o segundo ato.

No início do século XX, a disciplina de história se dedicava quase exclusivamente ao estudo de eventos políticos do passado. Os historiadores que começaram a escrever 
trabalhos que claramente não se limitavam ao estudo de eventos políticos passados tiveram que ouvir incontáveis vezes "O que você está fazendo não é história". Eles tiveram que lutar pelo direito de usar o signo "história" para descrever os seus trabalhos. Mas conquistar o direito de usar o signo "história" não resolvia inteiramente o problema. Porque um trabalho idiossincrático podia ser ao mesmo tempo classificado como um trabalho historiográfico e desclassificado como um trabalho historiográfico de baixa qualidade (SEABRA, 2012, 2014). Segundo Lacoste, os geógrafos que se interessavam por geopolítica enfrentaram dificuldades semelhantes (LACOSTE, 2001).

O que a filosofia pode ganhar com a consideração das transformações pelas quais passaram ao longo do século $\mathrm{XX}$ as disciplinas de história e geografia? Ela pode ganhar a consciência de que é possível, sim, ampliar os seus limites temáticos e metodológicos sem descaracterizá-la. Uma parte considerável dos trabalhos historiográficos produzidos nos dias de hoje (que lançam mão de entrevistas e pesquisas quantitativas, que utilizam fontes não oficiais, que não se limitam a escrever a história do ponto de vista das elites, que tentam descrever estruturas ao invés de simplesmente organizar os grandes eventos históricos em narrativas etc.) certamente não seriam considerados como trabalhos historiográficos no início do século XX, o que não significa de forma alguma que não sejam exemplos perfeitamente válidos e solidamente paradigmáticos de trabalhos historiográficos. Se a historiografia passou por transformações fabris profundas sem ser descaracterizada, sem deixar de ser historiografia, por 
NEUTRALIZANDO 0 ARGUMENTO DA QUALIDADE: RESULTADOS PRELIMINARES...

que a filosofia não poderia também passar por transformações fabris profundas sem ser descaracterizada, sem deixar de ser filosofia?

Como a filosofia experimental parece já estar bem consolidada no cenário filosófico internacional, talvez não seja mais necessário defender que é possível fazer pesquisas empíricas sem sair do campo da filosofia. No entanto, a acusação de não ser filosófico por descer do mundo das ideias e levar a luta para o chão está longe de esgotar as críticas realizadas ao presente estudo. ${ }^{18}$ Uma das coisas de que ele foi frequentemente acusado em suas etapas preparatórias pelo simples fato de recorrer a métodos quantitativos foi a de ser positivista. Trata-se de uma acusação fortemente derrogatória muito mais fácil de proferir do que de substanciar. Em sua acepção atual, que mantém tanto semelhanças quanto diferençasem relação à sua acepção original, o adjetivo "positivista" descreve uma atitude intelectual maculada por dois pecados básicos, um epistemológico e outro político. Do ponto de vista epistemológico, ele acredita em fatos, em verdades. Ele acredita que é possível descrever a realidade, mesmo que imperfeitamente. Do ponto de vista político, o positivismo é conservador. Tanto num caso como no outro, a sua marca fundamental é a ingenuidade. Portanto, ser acusado de positivismo é tão pouco lisonjeiro quanto ser acusado de incompetência. No ambiente acadêmico, o termo "positivista" está para as interações linguísticas assim como um soco está para as interações físicas. Não há dúvida de que ele possui um tom negativo. Não há problema algum em ser conhecido no meio acadêmico como "fenomenólogo" ou como "existencialista". Mas se você for conhecido como "positivista”, você estará carregando um terrível estigma. 
A acusação de que a presente pesquisa é de natureza positivista, porém, constitui apenas uma confissão dadificuldade de pensar fora de categoriasinapropriadas para descrevê-la. Obviamente, não é fácil entender como uma pesquisa que visa trazer preconceitos inconscientes à tona possa ser classificada como politicamente conservadora. $\mathrm{O}$ que há de conservador em mostrar que os membros da comunidade brasileira de filosofia, na hora de avaliarem a qualidade de textos filosóficos, levam em consideração algo tão irrelevante como a nacionalidade dos seus autores? O que há de conservador emmostrar que, reproduzindo a divisão geopolítica entre países desenvolvidos e países em desenvolvimento em suas ranhuras retinianas, eles tendem a considerá-los mais bem elaborados e dignos de serem publicados quando são assinados por franceses do que quando são assinados por brasileiros? Seguir inconscientemente uma estrutura de poder é uma coisa. Explicitá-la é outra coisa. Aliás, talvez a forma mais eficiente de garantir a perpetuação de uma estrutura de poder seja negando a sua existência, enão há como combatê-lasem antes reconhecer a sua existência. Se a presente pesquisa tivesse sido concebida não por brasileiros, mas por franceses, será que ela seria vista como positivista? Ou será que ela seria vista como obra de pensadores revolucionários que não deixam as fronteiras disciplinares da filosofia refrearem a sua luta contra estruturas de poder internalizadas e reproduzidas de forma involuntáriae irrefletida?

Do ponto de vista epistemológico, é difícil entender em que sentido pode ser ingênuo acreditar na existência de fatos. Sem dúvida, é ingênuo acreditar que eles não podem 
NEUTRALIZANDO 0 ARGUMENTO DA QUALIDADE: RESULTADOS PRELIMINARES...

ser jamais distorcidos. Mas se eles podem ser distorcidos, é porque há algo a se distorcer (FRICKER, 2011). É necessário que existam fatos para que se possa falar em distorções de fatos. Seria uma distorção dos fatos dizer que os autores europeus foram favorecidos nos Excertos 2 e 3. Mas também seria uma distorção dos fatos dizer que o autor francês não foi favorecido no Excerto 1. O que há de politicamente desejável em se negar que não é um fato que as mulheres e os negros são discriminados? Apesar do que reza o método estruturalista de leitura, não há problema algum em ler o pós-modernismo de forma crítica, separando o joio do trigo. ${ }^{19}$ Aquilo que os defensores da ideia de que não existem fatos e verdades fazem não é provar que não existem fatos e verdades, apenas provar que é possível falar de fatos e verdades sem fazer uso explícito dos termos "fatos" e "verdades".

Mas também é possível ser racista sem fazer nenhuma referência verbal à noção de raça. Shiralee Hood, uma comediante aborígene, reconta uma piada que pode ajudar a entender esse fato (HOOD, 2016). Não muito tempo atrás os aborígenes só podiam sentar nos últimos assentos dos ônibus australianos. Um dia um senhor aborígene, cansado de ser discriminado em sua própria terra, decidiu se sentar em um dos assentos vazios da frente. Na próxima parada, um branco que subiu no ônibus se aproximou e disse "Eu quero sentar aqui. Como você pode ver, há assentos vazios no fundo do ônibus". O senhor aborígene respondeu: "Eu já estou sentado aqui. Como você também pode ver, há assentos vazios no fundo do ônibus". A briga logo assumiu dimensões físicas. O motorista parou o ônibus e pediu que todos os passageiros descessem para que pudessem conversar e resolver a situação. "Como foi que começou essa confusão?", perguntou quando todo mundo 
já estava do lado de fora. "Os negros não podem sentar na frente", disse o branco. "Os hóspedes não podem mandar em seus anfitriões", respondeu o aborígene. O motorista, que era branco, então falou: "Já é hora de acabarmos com a distinção entre brancos e negros. Agora todo mundo aqui é verde. Não existem pessoas brancas nem pessoas negras. Apenas pessoas verdes." Os passageiros acharam a proposta justa. "Agora que o problema está resolvido, entrem no ônibus de novo", continuou o motorista. "Se você for verde claro, por favor, sente na parte dianteira do ônibus, e se for verde escuro, sente na parte traseira".

O fato de que o presente estudo se ancora em dados empíricose análises estatísticas não significa que possa ser completamente absorvido pelo positivismo. $O$ fato de que identifica estruturas subliminares de poder e sujeitos paradoxalmente trabalhando contra si mesmos não significa que possa ser completamente absorvido pelo pós-modernismo. Aliás, o seu comprometimento político o afasta decisivamente do positivismo, e o seu uso de métodos quantitativos o afasta irremediavelmente do pós-modernismo. "Sempre nos afiliamos a movimentos estrangeiros", escreveu Afrânio Coutinho. "Até mesmo a reação contra uma corrente estrangeira se baseia em outra corrente igualmente estrangeira" (COUTINHO, 1943, p.187). ${ }^{20} \mathrm{O}$ diagnóstico talvez tenha algo de verdade. Ele toca em um tema frequentemente discutido na literatura sobre a filosofia brasileira:

A Filosofia no Brasil sempre foi um produto de importação. (...) Na Colônia, a escolástica importada de Coimbra; no Império, o ecletismo; a seguir o positivismo e o evolucionismo, que chegaram até a República. 
NEUTRALIZANDO 0 ARGUMENTO DA QUALIDADE: RESULTADOS PRELIMINARES...

Depois, o neo-kantismo, um pouco de bergsonismo, muito ralo; o marxismo, o existencialismo e até Husserl, Hartmann e Heidegger! (...) Até a fundação da Faculdade de Filosofia, o filoneísmo dominou nossa cultura. (CRUZ COSTA, 1975, p.91)

Da filosofia de nossos filósofos, dir-se-ia, não importa muito falar, porque seu pensamento, ao final de contas, não é mais do que um eco apagado e confuso daquilo que já havia sido pensado por outros, em outros lugares, e com maior clareza e precisão. (...) E se pensarmos sobre o que sempre foram nossas circunstâncias históricas, poderemos muito bem chegar à conclusão de que esta recepção não poderia estar senão inevitavelmente condicionada pela instabilidade institucional, pela falta de continuidade das políticas universitárias, pela cíclica escassez de recursos e pela reconhecida subordinação do pensamento aos interesses e urgências da hora (...). Um modo (...) de reconhecer que nossa única originalidade seria aquela que brota das distorções e limitações impostas pela indigência, pela improvisação, e pela superficialidade. (CAPONI, 2003, p.49)

O que temos aqui, porém, talvez não seja um diagnóstico neutro e objetivo, mas antes a confissão de que as nossas retinas estão gravadas de tal maneira que bloqueiam por princípio o valor de toda e qualquer manifestação filosófica oriunda dos países em desenvolvimento. O beco não tem saída. Se você concordar em abaixar a cabeça e ser um mero comentador, você estará fazendo um trabalho sério, mas não um trabalho original. Você ganhará o respeito da sua comunidade filosófica, mas não estará verdadeiramente 
trazendo nenhuma contribuição para o seu campo. Se você se recusar a abaixar a cabeça e ser um mero comentador, você estará fazendo talvez um trabalho original, mas certamente não um trabalho sério. Você poderá estar verdadeiramente trazendo uma contribuição para o seu campo, mas perderá o respeito da sua comunidade. ${ }^{21} \mathrm{O}$ fato de que o presente estudo tende a ser identificado ora ao positivismo, ora ao pósmodernismo, tem a algo a dizer menos sobre o seu conteúdo do que sobre as estruturas gravadas em nossas retinas. Mas se o presente estudo não se alinha nem ao positivismo nem ao pós-modernismo, com que tradição ele se alinha? Como classificá-lo? Como avaliá-lo? Para sabê-lo, é preciso realizar uma atividade enganosamente simples: ler.

A presente pesquisa surgiu do reconhecimento de que certos debatesprecisam ser levados para o chão. Os críticos de Porchat, Armijos, Cabrera e Margutti são perfeitamente capazes de rebater os seus argumentos com argumentos igualmente fortes e bem elaborados. Não é possível rebater o argumento da qualidade sem expandir as ferramentas normalmente utilizadas pela filosofia. O que a filosofia deve fazer quando chegaem suas próprias fronteiras não é recuar. O que ela deve fazer é questioná-las e avançar. ${ }^{22}$

Os estudantes de filosofia podem se formar e geralmente se formam sem terem lido sequer um filósofo brasileiro. $\mathrm{E}$ também sem terem lido sequer um filósofo latino-americano. E também sequer um filósofo africano. E também sequer um filósofo asiático. E a quantidade de filósofas que leem 
NEUTRALIZANDO 0 ARGUMENTO DA QUALIDADE: RESULTADOS PRELIMINARES...

certamente não faz justiça à quantidade de filósofas que escrevem (HASLANGER, 2008; WUENSCH, 2015). Para se evitar a acusação de que os currículos dos cursos de filosofia excluem tantos autores de forma injusta - e de que eles são portanto deploravelmente falhos e incompletos - é preciso negar a própria existência dos excluídos. Pois os autores que não existem não podem ter sido excluídos. Mas quando a existência deles vem à tona com uma força tal que não pode ser negada, o alvo passa imediatamente a ser a qualidade da sua produção. Mas é bem provável que não seja realmente a baixa qualidade o critério utilizado para excluí-los da sala de aula. Pois o que os resultados apresentados aqui sugerem é que um texto de filosofia assinado por um autor francês tem muito mais chances de ser visto como um texto interessante pela comunidade filosófica brasileira (o que certamente aumenta as suas chances de circular, de ser citado, de ser utilizado em sala de aula, etc.) do que um texto idêntico (portanto, de igual qualidade) assinado por um autor brasileiro.

Os membros da comunidade filosófica brasileira não irão franzir o cenho caso você diga que está escrevendo sobre a filosofia de Wittgenstein ou de Heidegger. Os continentais poderão, sem dúvida, olhá-lo de forma atravessada caso você esteja lendo Wittgenstein ao invés de Heidegger, e os analíticos poderão fazer o mesmo caso você esteja lendo Heidegger ao invés de Wittgenstein. Contudo, é bem mais provável, nos dias de hoje, que os especialistas em filósofos continentais e os especialistas em filósofos analíticos mantenham relações amistosas, embora possam ser bastante críticos com as tradições intelectuais uns dos outros. Mas se você estiver 
lendo Puntel, por exemplo, as coisas tenderão se processar de maneira bastante diferente. Em primeiro lugar, porque tratase de um autor quase inteiramente desconhecido dentro das fronteiras nacionais. Em segundo lugar, e mais importante, porque trata-se de um autor de nacionalidade brasileira. Mas se você colocar nas mãos do seu interlocutor o denso e pesado Structureandbeing (PUNTEL, 2008), ele se sentirá mais tranquilo, caminhando de novo em território conhecido. Caso a obra de Puntel não consiga por si só aplacar as desconfianças semiconscientes induzidas por sua nacionalidade, talvez valha a pena mencionar que ele trabalha na Alemanha. O que há nele de tropical é preocupante. O que há nele de setentrional é reconfortante.

Mas a mesma duvidosa generosidade não é estendida para autores brasileiros - nem para autores latino-americanos, africanos e asiáticos - que só têm a apresentar a qualidade daquilo que escrevem. Se você estiver escrevendo sobre - ou simplesmente lendo - um autor como Cabrera, por exemplo, você não será olhado com incerteza. Você será olhado de cima para baixo com conviç̧ão, pois os ingredientes setentrionais que certamente podem ser encontrados em Cabrera não obliteram completamente os seus ingredientes tropicais. Com efeito, pelo simples fato de trabalhar não em um país desenvolvido, mas em um país em desenvolvimento, ele possui ingredientes tropicais demais para ser aceito como um filósofo sério. E caso a sua obra demonstre ser de valor inegável, as dosagens de ingredientes tropicais e setentrionais irão subitamente se inverter, e ele passará a ser visto como possuindo ingredientes setentrionais demais 
NEUTRALIZANDO 0 ARGUMENTO DA QUALIDADE: RESULTADOS PRELIMINARES...

para ser aceito como um verdadeiro exemplo de pensador original proveniente de um país em desenvolvimento. Talvez passagens como as seguintes tenham deixado marcas indeléveis nas retinas da comunidade filosófica brasileira:

Parece também que a organização do cérebro é menos perfeita nos dois extremos. Nem os negros nem os lapões têm a inteligência dos europeus. (ROUSSEAU, 2009, p.32)

Mansidão e indiferença, humildade e submissão perante um crioulo, e mais ainda perante um europeu, são as principais características dos americanos do sul, e ainda custará muito até que europeus lá cheguem para incutirlhes uma dignidade própria. A inferioridade desses indivíduos, sob todos os aspectos, até mesmo o da estatura, é fácil de se reconhecer. (HEGEL, 2008, p.75)

Nada se compara, porém, à animosidade que você lerá nos olhos do seu interlocutor caso você ouse colocar as suas próprias sacadas no papel. ${ }^{23}$ Você provavelmente será olhado de cima para baixo antes mesmo de ser lido. E você precisará de muita sorte até mesmo para ser lido. Alheio ao fato de que para se compreender adequadamente os gestos que abrem um texto se faz necessário lê-lo por inteiro, o seu interlocutor, mesmo que seja especialista em hermenêutica, encontrará problemas sérios já em suas primeiras palavras. Pois o problema não está exatamente no que você escreveu. $\mathrm{O}$ problema está no simples fato de que você escreveu. O problema não é oque, o problema é quem. 


\begin{tabular}{|c|c|c|}
\hline Distribuição geogrâfica das capacidades intelectuais & Europeus & Latino-americanos \\
\hline $\begin{array}{c}\text { Capacidade de reter informações } \\
\text { (por exemplo, conseguir memorizar passagens, saber localizar } \\
\text { citações, ter grande erudição etc.) }\end{array}$ & $\checkmark$ & $\checkmark$ \\
\hline $\begin{array}{l}\text { Capacidade de manipular informações } \\
\text { (por exemplo, conseguir elucidar sentidos, extrair conclusões, } \\
\text { identificar contra dições etc.) }\end{array}$ & $\checkmark$ & $\checkmark$ \\
\hline $\begin{array}{c}\text { Capacidade de gerar informações } \\
\text { (por exemplo, conseguir produzir ideias filosóficas originais e } \\
\text { profundas, criar sistemas e teorias etc.) }\end{array}$ & $\checkmark$ & $\mathrm{x}$ \\
\hline
\end{tabular}

Tabela 3:Diferenças entre as capacidades intelectuaisdos pensadores europeus e pensadores latino-americanos segundo o imaginário da comunidade filosófica brasileira.

No imaginário da comunidade filosófica brasileira, o pensador brasileiro parece possuir apenas duas funções cognitivas operantes: a memória (a capacidade de armazenar informações) e o raciocínio (a capacidade de analisá-las e interpretá-las). Apenas os europeus e norte-americanos possuem intelectos plenamente desenvolvidos. ${ }^{24}$ Seguese que o pensador brasileiro está bem talhado para a tarefa de comentar. O que ele escreve só pode ser bom na medida em que não for ousado, em que não for original, em que não for inovador. $\mathrm{O}$ que ele escreve só pode ser bom na medida em que for modesto e comedido - na medida em que respeitar a ordem internacional que reserva aos países 
desenvolvidos a tarefa de desbravar o desconhecido e aos países em desenvolvimento a tarefa de seguir os seus passos. O que ele escreve só pode ser bom se não for bom. Ou melhor, o que ele escreve pode e deve ser bom; porém, não pode ultrapassar o limite do meramente bom. Não pode ser genial. Não pode ser original. Não pode ser profundo. Não pode ser relevante. Por princípio. Assim, longe de serem estimulados a pensar, os estudantes de filosofia brasileiros são brutalmente estigmatizados quando se aventuram desavisadamente a fazê-lo. Eles precisam refrear todo e qualquer impulso que porventura possam ter de colocar no papel as suas próprias reflexões, limitando-se obedientemente a colocar no papel apenas as suas reflexões sobre as reflexões alheias. Não é de bom tom filosofar:

Para começar, cometi um pecado mortal, embora não tenha sido o único nem o primeiro, dando a entender que estava levando a sério a filosofia brasileira. (ARANTES, 1995, pp.184-185)

A etiqueta filosófica brasileira parece exigir que não se filosofe em nome próprio, e que não se argumente em causa própria; dever-se-á sempre fazê-lo em nome dos autores consagrados, e reforçando a autoridade deles e a sua sempre renovada vigência. (CAPONI, 2003, p.59)

Embora a filosofia, na contemporaneidade, seja produzida nos cinco continentes e com conceitos importantes sendo produzidos em todos eles, o locus privilegiado de enunciação da filosofia segue sendo eurocêntrico. A marca mais importante deste fenômeno se mostra no fato de que nos currículos dos cursos de 
filosofia de todo o mundo aparece um cânone comum que é basicamente europeu (com parcas contribuições norte-americanas). A própria historiografia da filosofia é eurocentrada, o que acaba por invisibilizar as produções existentes fora da Europa e Estados Unidos. (NASCIMENTO \& BOTELHO, 2010, p.82)

E mais uma vez encontramos aqui os nossos quatro autores principais:

Há determinadas ocasiões em que percebemos que, em algum sentido importante, não estamos em sintonia com o mundo. (...) Quando era estudante da graduação em filosofia e estava prestes a me formar, me perguntaram sobre quem iria escrever a dissertação. Naquela ocasião, também, fiquei entre mudo e boquiaberto. Pois naquele instante percebi o que talvez fosse uma obrigação de todo estudante de filosofia: escrever a dissertação, necessariamente, sobre alguém. Na verdade, não tinha passado pela minha cabeça que era minha obrigação escrever sobre alguém, como outros achavam - e, lamentavelmente, ainda acham - mas sobre algum problema filosófico que me incomodasse, me preocupasse e merecesse alguma tentativa de solução racional. Eventualmente, poderia escrever contra alguém - contra as ideias de algum filósofo, isto é - mas não necessariamente sobre esse pensador. (ARMIJOS, 2008, pp.101-2)

É lamentável que alguns historiadores da Filosofia, ilustres e de indiscutível valor em sua área de pesquisa, nos tenham querido fazer acreditar que se pôr a filosofar 
NEUTRALIZANDO 0 ARGUMENTO DA QUALIDADE: RESULTADOS PRELIMINARES...

pressupõe a crença na própria genialidade. Nada conheço de mais castrador do que essa tese, quando arremessada sobre a cabeça de um jovem que se propõe a estudar e praticar a Filosofia. Mas ela é falsa. Ela é tão falsa em Filosofia quanto é obviamente falsa em qualquer outro ramo do saber teórico ou prático dos homens. (PORCHAT, 2010, p.32)

Esta costuma ser uma das maiores preocupações do filósofo acadêmico profissional. E quando palestramos em algum lugar tentando expor nossos próprios pensamentos, é comum notarmos uma tensão muito forte em nossos cultos ouvintes, como se estivessem forçando suas mentes na tentativa de lembrar onde eles já leram ou escutaram coisas parecidas, e as repetições e semelhanças, se descobertas, serão destacadas com especial satisfação no debate posterior. (CABRERA, 2010, p.137)

Em consequência, aquele pesquisador que baixa a cabeça à assim chamada superioridade cultural europeia e se dedica humildemente ao comentário dos textos clássicos é elogiado e respeitado, enquanto aquele pesquisador que não baixa a cabeça e se atreve a elaborar uma visão própria (...) é fortemente criticado e desrespeitado pelos seus pares, quando não simplesmente ignorado por ser indigno de consideração. (MARGUTTI, 2014b, p.6). 
A expectativa da comunidade filosófica brasileira parece sera seguinte: os brasileiros são perfeitamente capazes de escrever comentários inexpressivos, mas não de desenvolverem ideias originais, ideias que valham a pena contemplar, examinar, absorver e explorar. Aliás, seria melhor se eles não tentassem fazer o que por princípio são incapazes de fazer. $\mathrm{Na}$ economia mundial do saber, cabe aos autores dos países desenvolvidos produzir filosofia, e aos autores dos países em desenvolvimento consumi-la.

Quando você se põe a ler um autor como Cabrera, você está se aliando a um autor que não respeita a divisão internacional do trabalho intelectual. Mas quando você coloca as suas próprias ideias no papel, então é você mesmo que se torna o perturbador da ordem. O estigma que o afetava indiretamente por ler aquilo que não deveria passa a afetá-lo diretamente por escrever aquilo que não deveria. Você pode ser perdoado pelo que lê. Porém, não pelo que escreve. Mas forçar os pensadores brasileiros a produzirem única e exclusivamente comentários - sem deixar que os seus pensamentos se organizem de forma natural, segundo a sua própria lógica interna -, é submetê-los a uma intervenção violentamente inibidora, que pode inclusive comprometer seriamente a sua capacidade de julgamento. Porque, rigorosamente falando, os resultados obtidos no Excerto 1 não permitem facilmente saber se os membros da comunidade filosófica brasileira tendema ser excessivamente críticos com os pensadores brasileiros ou excessivamente lenientes com os pensadores franceses. Ao invés de estarem colocando as suas faculdades críticas para funcionarem a 
NEUTRALIZANDO 0 ARGUMENTO DA QUALIDADE: RESULTADOS PRELIMINARES...

todo vapor ao lerem pensadores brasileiros, eles podem estar se esquecendo de exercê-las adequadamente ao lerem pensadores franceses. Talvez eles sejam maus leitores tanto de pensadores brasileiros (e latino-americanos, africanos e asiáticos) quanto de pensadores franceses (e europeus e norte-americanos). Talvez eles leiam os textos dos brasileiros ajustando-os às suas ranhuras retinianas, e leiam os textos dos franceses ajustando a eles as suas ranhuras retinianas.

A mentalidade na qual vivemos e que vive dentro de nós está para os nossos pensamentos mais ou menos como os trilhos estão para os trens. É extremamente difícil sentila guiando os nossos julgamentos e opiniões com os seus gestos ao mesmo tempo delicados e firmes. Elaborar ideias, conceitos e teorias que contrariem estruturas cognitivas profundamente incrustadas em nosso ser constitui uma tarefa necessariamente penosa. É seguramente mais fácil, muito mais fácil, deixar que a mentalidade dominante oriente o fluxo dos nossos pensamentos. Pois ela está sempre maquinando, dos recessos das nossas consciências, contra todas as nossas tentativas de trazê-la à tona, de criticála e de contrariá-la. Porém, não é possível fazer filosofia sem desafiar as associações implícitas e automáticas que carregamos no peito. Não é possível fazer filosofia sem travar uma luta interior consigo mesmo. 


\begin{tabular}{|c|c|}
\hline \multicolumn{2}{|c|}{ Dicotomias estrutura doras da civilização ocidental } \\
\hline Itens valonizados & Itens desvalorizados \\
\hline Mente & Corpo \\
\hline Pensar & Sentir \\
\hline Abstrato & Concreto \\
\hline Trabalho intelectual & Trabalho braçal \\
\hline Ativo & Passivo \\
\hline Produção & Reprodução \\
\hline Seres humanos & Outros animais \\
\hline Cultura & Natureza \\
\hline Homens & Mulheres \\
\hline Brancos & Negros \\
\hline Ricos & Pobres \\
\hline Adultos & Crianças \\
\hline Colonizadores & Colonizados \\
\hline Cidade & Campo \\
\hline Autores de paises desenvolvidos & Autores de paises em desenvolvimento \\
\hline
\end{tabular}

Tabela 4: Algumas das dicotomias estruturadoras da civilização ocidental. A lista se inspira no trabalho da ecofeministaVal Plumwood (1997).

Parece que a civilização - com todas as suas hierarquias sociais e epistêmicas - funciona mesmo como uma espécie de estrutura transcendental. Os seus habitantes carregam dentro de si um sistema de coordenadas extremamente complexo que tem o poder de escapar ao controle da 
NEUTRALIZANDO 0 ARGUMENTO DA QUALIDADE: RESULTADOS PRELIMINARES...

consciência e de silenciosamente estruturaros seus aparatos cognitivos, distorcendo significativamente a sua forma de ver e julgar o mundo e uns aos outros. As suas subjetividades carregam obediente, cuidadosa e meticulosamente o sistema de hierarquias que ordena a civilização - daí o fato de mesmo pessoas discriminadas por causa de um determinador fator também discriminarem por causa do mesmo fator. Os membros da comunidade filosófica brasileira aparentemente reproduzem em sua própria escala o dualismo estruturador da civilização ocidental descrito habilmente por Val Plumwood (1997). A negação (menos verbal do que emocional, menos afirmada do que presumida) da capacidade de pensar dos autores brasileiros talvez seja um desdobramento estrutural dessa mentalidade que supervaloriza a mente em detrimento do corpo, o pensar em detrimento do sentir, o abstrato em detrimento do concreto, o trabalho intelectual em detrimento do trabalho braçal, os seres humanos em detrimento dos outros animais, os homens em detrimento das mulheres, os brancos em detrimento dos negros, os ricos em detrimento dos pobres, os adultos em detrimento das crianças, os colonizadores em detrimento dos colonizados, a cidade em detrimento do campo, e os autores dos países desenvolvidos em detrimento dos autores dos países em desenvolvimento, numa série aparentemente infinita que obsessivamente classifica e hierarquiza tudo o que encontra em seu caminho.

Mas nem todas as ideias que nos ocorrem seguem obedientemente a geopolítica do saber. Às vezes elas se confundem e despontam na cabeça de pessoas que nasceram 
com a nacionalidade errada. Ou com o gênero errado (HASLANGER, 2008; WUENSCH, 2015). Ou com a cor da pele errada (BERNASCONI \& COOK, 2003; VALLS, 2005; PARK, 2013). Frequentemente, elas estão simplesmente seguindo a cartilha, seja ela uma cartilha antiga, seja ela uma cartilha que acabou de chegar. Mas elas podem também ser manifestações profundas do nosso ser - inquietações com inconsistências, frustrações com injustiças, intuições de alternativas. Quando viramos as costas para elas, viramos as costas para nós mesmos. As ideias gostam de testar suas próprias forças. Elas não temem descarrilhar. Tentar submetê-las a uma triagem para deixar somente aquelas que se conformam à cartilha verem a luz do dia é como tentar impedir o coração de bater. Quando o nosso ser se sente livre para se expressar, sentimo-nos vivos e energizados. Mas quando somos forçados a obedecer a regras que restringem tanto a forma quanto o conteúdo dos nossos pensamentos, então não temos outra alternativa a não ser retroceder, num movimento concentrado de aparente desistência, para reunir energias interiores e avançar contra as barreiras que impedem a nossa livre expressão. A rígida e massificada marcha militar certamente leva ao progresso. Mas o pensamento precisa também tirar o uniforme. Para não perder a cor e recuar para dentro de si mesmo, ele precisase permitir fazer o que é capaz fazer. $^{25}$ 
NEUTRALIZANDO 0 ARGUMENTO DA QUALIDADE: RESULTADOS PRELIMINARES...

\section{NOTAS}

${ }^{1}$ Doutorando em Filosofia pela La TrobeUniversity, Australia. E-mail: muriloseabra@gmail.com.

${ }^{2} \mathrm{PhD}$ em Spanish Linguistics and Discourse Analysys, University of Queensland, Australia.Lecturer, La Trobe University, Australia. E-mail: l.tolton@latrobe.edu.au.

${ }^{3}$ B.ScHons, Ph.DLaTrobe.Head, Department of Mathematics and Statistics, Associate Professor, La Trobe University, Australia.E-mail:luke. prendergast@latrobe.edu.au.

${ }^{4}$ A entrevista original foi dada em inglês:

My family has been doing this kind of fight back in Brazil for over 75 years. In Brazil nobody knew about it. Once it came to America, it spread all over the world. (GRACIE, 1994).

Como se pode ver pelas referências temporais, a entrevista que aparece nos extras do DVD foi dada muitos anos depois do UFC 1. A arte desenvolvida pela família Gracie alcançou um certo reconhecimento dentro do Brasil antes de ser levada para os Estados Unidos. No entanto, ela só se tornou amplamente respeitada e admirada em território nacional depois que conquistou reconhecimento internacional. Um processo semelhante parece ter acontecido com Newton da Costa.

${ }^{5} \mathrm{O}$ artigo original está em inglês:

The Europeans never doubted that the Indians had bodies - animals have them as well - and the Indians in turn never doubted that the Europeans had souls, since animals and the ghosts of the dead do as well. Thus the Europeans' ethnocentrism consisted in doubting that the body of the other contained a soul formally similar to the one inhabiting their bodies, and the Indians', on the contrary, entailed doubting that the others' souls or spirits could possess a body materially similar to theirs. (VIVEIROS DE CASTRO, 2013, pp.21-22) 
${ }^{6}$ Os filósofos pós-coloniais começaram progressivamente a aparecer nos escritos de Cabrera sobre o assunto. A maior parte dos trabalhos que discute o problema da filosofia brasileira, porém, não traz indicações de familiaridade com os filósofos pós-coloniais.

${ }^{7}$ Embora o México também faça parte da América do Norte do ponto de vista geográfico, a expressão "norte-americano"podee deve ser entendida aqui como se referindo exclusivamente aos Estados Unidos e ao Canadá. ${ }^{8}$ Só foram analisados os títulos dos capítulos das teses que não traziam já em seus títulos referências explícitas a autores europeus ou norteamericanos.

${ }^{9}$ Das universidades onde os questionários foram aplicados, cinco eram universidades de prestígio no cenário nacional, contendo programas de mestrado e doutorado. Apenas cinco questionários foram respondidos por participantes de universidades de menor prestígio, todos eles professores.

${ }^{10}$ O questionário foi desenhado por Murilo Seabra, com a ajuda de Marcos Pinheiro, Gabriel Silveira, Ralph Newmark, Rowan Ireland e Raul Sanchez Urribarri, a partir de um questionário anterior, aplicado em 2009, porém em uma escala bem menor, desenhado por Murilo Seabra, com a ajuda de Marcos Pinheiro, Gabriel Silveira, Roberto Sobral e Juliana Merçon (embora os resultados nunca tenham sido publicados, eles motivaram uma série de reflexões (SEABRA, 2014)). As análises estatísticas foram realizadas por Luke Prendergast e complementadas por análises mais simples de Murilo Seabra. A aplicação do questionário foi realizada e coordenada por Murilo Seabra, com a ajuda de Marcos Pinheiro, Gabriel Silveira, Lúcio Verçoza, Roberto Ballerini, Rodrigo Guimarães e Leonardo Reis. Murilo Seabra e Marcos Pinheiro digitaram as respostas dos participantes. Gabriel Silveira ajudou na codificação de algumas respostas de difícil tratamento. Um grande número de pessoas colaborou de maneira importante em todas as etapas da pesquisa, especialmente Jorge Alam Pereira dos Santos, Thomas Tolton, Amy Tolton, Alexander Currie, Iñaki López Corral, Arnold Ho, Daniela Souza, Ana Miriam Wuensch, Wanderson Nascimento, José Jorge de Carvalho, Priscila Funchal, Eduardo Bittencourt, Daniel Medeiros, Victor Abrão, Juliana de Orione, Luzinete Pereira da Silva, Susanne Dinger, Ronaldo Dienstmann, Samir Gorsky e Tina Nort.

${ }^{11}$ Quatro questionários foram excluídos da amostra, gerando o total de 93 questionários. Um deles foi excluído porque um dos participantes 
corretamente identificou o verdadeiro autor de um dos excertos. Um segundo questionário foi excluído porque o participante não era membro da comunidade filosófica, como indicado pelo próprio participante na folha de identificação. Os demais foram excluídos por causa de problemas na folha de identificação, problemas que tornavam duvidosa a validade dos dados coletados.

${ }^{12} \mathrm{O}$ editor da revista solicitou que os excertos utilizados nos questionários não fossem aqui reproduzidos por motivos de espaço. Mas é importante frisar que o Excerto 1 trazia uma temática ambiental, o Excerto 2 criticava a filosofia analítica e o Excerto 3 criticava a filosofia pós-moderna. Os participantes então tinham que informar, utilizando uma escala de 5 pontos, o seu grau de concordância ou discordância em relação a enunciados avaliativos como "Considerando que criticar aquilo que está na base dos nossos discursos consiste em realizar o que é conhecido na literatura como contradição performativa, podemos dizer que o autor está incorrendo em uma espécie de contradição performativa ao fazer uso do computador para criticar a civilização moderna", "A afirmação de que a filosofia analítica é um movimento estético distorce ao invés de elucidar a sua verdadeira natureza", "O autor deixou suas preocupações políticas assumirem uma importância grande demais, prejudicando a argumentação" e "O autor pinta uma imagem distorcida da filosofia pósmoderna”.

${ }^{13}$ Todos os valores-p apresentados aqui foram calculados utilizando-se as duas variáveis de controle que produziram valores-p mais elevados.

${ }^{14}$ Trata-se de uma convenção amplamente utilizada, mas que também tem sido sistematicamente questionada. Dependendo da natureza da pesquisa, um valor um pouco acima de 0,05 também pode ser significativo.

${ }^{15}$ Existem ainda outros indícios de coerência interna dos dados. Por exemplo, houve uma correspondência entre as idades dos participantes e as suas avaliações do Excerto 1 (o que faz perfeito sentido, dado o seu teor):

\begin{tabular}{|c|c|c|c|c|}
\hline Notas dadas para o Excerto 1 & Abaixo de 0,00 & Entre 0,1 e 1,0 & Entre 1,1 1 1,5 & Entre 1,6 e 2,0 \\
\hline Idade média dos participantes & 44,4 & 42,3 & 40,2 & 37,8 \\
\hline
\end{tabular}


Embora a idade média dos participantes que responderam o questionário $\mathrm{A}$ tenha sido três anos mais baixa que a dos participantes que responderam o questionário $\mathrm{B}$, as análises indicaram que essas diferenças não afetaram os resultados (por exemplo, quando as respostas dos participantes nascidos na década de 1960 que receberam o questionário A são comparadas com as dos participantes nascidos na década de 1960 que receberam o questionário B, é possível constatar que os primeiros avaliaram o Excerto 1 de forma mais positiva do que os segundos).

${ }^{16}$ Os dados parecem não trazer nada mais de estatisticamente significativo. Os resultados mencionados aqui foram obtidos e confirmados utilizandose diferentes métodos e modelos. Espera-se que uma análise mais completa dos dados possa ser publicada posteriormente.

${ }^{17}$ No segundo semestre de 2015, houve uma segunda coleta de dados com um instrumento ao mesmo tempo simplificado e aperfeiçoado. O excerto utilizado foi o seguinte:

Descobrir como ocorre o processo de extração de minerais - sem os quais a civilização moderna não poderia ter vindo a existir - gera um efeito análogo ao de descobrir como funciona a indústria da carne. Como podem esclarecer as pessoas que depois de idas e vindas resolvem se render a uma dieta vegetariana, torna-se difícil levar o garfo à boca com a mesma tranquilidade de antes. A indústria mineradora inspira uma reação semelhante. Entretanto, agora o desconforto não é com a carne que pegamos com o garfo. É com o garfo que usamos para pegá-la. É com a faca que usamos para cortá-la. É com a panela que usamos para prepará-la. É com o carro que usamos para ir trabalhar. É com o piercing com o qual demonstramos rebeldia. (...) É com a câmera que usamos para filmar, inclusive para filmar documentários sobre o relacionamento entre os aparelhos eletrônicos e a mineração, como Blood in the mobile [Sangue no telefone móvel], do diretor Frank Piasecki Poulsen. É com o computador que usamos para escrever, inclusive o que estou aqui escrevendo agora. É com todo o universo metálico que nos cerca e que serve de esqueleto para a nossa civilização. 
Contudo, não estou incorrendo em uma espécie de contradição performativa ao criticar a civilização moderna? Não foi ela que confeccionou o computador que estou agora usando? E que me deu acesso às informações e à educação formal da qual estão gradativamente emergindo as minhas críticas? Mas a dependência das minhas críticas em relação à civilização é puramente material, não conceitual, e o que parece ser uma contradição lógica é, na verdade, uma genuína obrigação ética. Se minhas palavras soam contraditórias, é porque a civilização se tornou uma espécie de estrutura transcendental, funcionando como o pressuposto de toda a nossa vida. Os nossos pensamentos estão para a civilização assim como as locomotivas estão para os seus trilhos.

Um desastre ambiental de grande repercussão midiática (GALLAS, 2015), porém, tornou os dados inutilizáveis.

${ }^{18}$ Murilo Seabra coletou mais de vinte acusações diferentes. Elas vão desde a acusação de falta de originalidade até a acusação de se estar negando injustamente o valor do pensamento filosófico ocidental. A acusação mais frequentemente feita à presente pesquisa, porém, é a de que ela simplesmente inverte o preconceito que pretende combater. É difícil não lembrar aqui da acusação paralela frequentemente feita pelo público leigo ao feminismo, a saber, de que se trata simplesmente de um machismo invertido.

${ }^{19}$ Para mais informações sobre o método estruturalista de leitura, que não deve ser confundido com o estruturalismo de Lévi-Strauss (1964-1971), ver Caponi (2003) e Porchat (2010).

${ }^{20} \mathrm{O}$ artigo original está em inglês:

We always have been affiliated with foreign movements. (...) Even the reaction against one foreign current is based on another current equally foreign. (COUTINHO, 1943, p.187)

${ }^{21}$ Para uma discussão do conceito de originalidade, ver Seabra (2014).

${ }^{22}$ Uma leitura atenta do presente estudo certamente encontrará nele traços do estruturalismo lévi-straussiano (LÉVI-STRAUSS, 1964-1971), que não deve 
ser confundido com o método estruturalista de leitura (CAPONI, 2003; PORCHAT, 2010), e que pode ser visto como uma forma de pensar mais ameríndia do que francesa (VIVEIROS DE CASTRO, 2013).

${ }^{23}$ Para uma análise de como o termo sacada reverbera de forma diferente do termo insight na subjetividade dos membros da comunidade filosófica brasileira, ver Seabra (2014).

${ }^{24}$ É difícil não notar aqui as analogias com o período colonial, quando se discutia se os povos nativos eram apenas animais.

${ }^{25}$ Algumas das obras que aparecem na lista de referências bibliográficas não estão citadas na versão final do presente artigo, que precisou ser reduzido a pedido do editor. 
NEUTRALIZANDO 0 ARGUMENTO DA QUALIDADE: RESULTADOS PRELIMINARES...

\section{REFERÊNCIAS}

ARANTES, P. "Uma História dos Paulistas no seu desejo de ter uma Filosofia. Duas entrevistas com Paulo Arantes".In: Revista Trans/Form/Ação, No. 18, 1995, pp.183-198.

ARMIJOS, G. De como fazer Filosofia sem ser Grego, estar Morto ou ser Gênio. Goiânia: Ed. UFG, 2004.

ARMIJOS, G. "Perguntas Autoritárias: A Questão do Método, as Monografias e o Filosofar". In: Educação e Filosofia, Vol. 22, No. 44, jul./dez. 2008, pp.101-114.

BAZZO, E. A Arte de Cuspir ou A Dialética dos Porcos. Brasília: Lilith, 1994.

BAZZO, E. Toaletes e Guilhotinas: Uma Epistemologia da Merda e da Vingança. Brasília: LGE, 2008.

BAZZO, E. Inventário de Cretinices ou O Prazer de Jogar Pérolas aos Porcos. Brasília: Siglaviva, 2014.

BENSUSAN, H. "Observações sobre a Libido Colonizada: Tentando Pensar ao Largo do Patriarcado". In: Estudos Feministas, Vol. 12, No. 1, jan./abr. 2004, pp.131-155.

BENSUSAN, H. Excessos e Exceções: Por uma Ontologia sem Cabimento. São Paulo: Ideias e Letras, 2009.

BERNASCONI, R. \& COOK, S. Race and Racism in Continental Philosophy. Bloomington: Indiana University Press, 2003. 
BORSUK, R. et al. "To Name or Not to Name: The Effect of Changing Author Gender on Peer Review." In: BioScience, Vol. 59, No. 11, 2009, pp.985-989.

BROWNSTEIN, M. \& SAUL, J. Implicit Bias and Philosophy, Vol. 1: Metaphysics and Epistemology. Oxford: Oxford University Press, 2016a.

BROWNSTEIN, M. \& SAUL, J. Implicit Bias and Philosophy, Vol. 2: Moral Responsibility, Structural Injustice, and Ethics. Oxford: Oxford University Press, $2016 \mathrm{~b}$.

CABRERA, J. Diário de um Filósofo no Brasil. Ijuí: Ed. Unijuí, 2010.

CABRERA, J. "Estudo preliminar. Pensar Insurgente: Acerca da Inconstância de um Filosofar Selvagem (Filosofia no Brasil numa Perspectiva Latino-Americana)". In: Problemata: Revista Internacional de Filosofia, No. Especial, 2015a, pp.5-47.

CABRERA, J. "Europeu não significa Universal. Brasileiro não significa Nacional". In: Nabuco: Revista Brasileira de Humanidades. Vol. 1, No. 2, nov./dez. 2014, jan. 2015b, pp.1447.

CAPONI, G. "O Longo Braço de Goldschmidt: O Paradigma Uspiano na Filosofia Brasileira". In: Tempo e Ciência, Vol. 10, Nos. 19-20, jan./jun. 2003, pp.47-65.

CARVALHO, E. "Ezio Flavio Bazzo, Inventário de cretinices: ou o prazer de jogar pérolas aos porcos." In: Estudos de Literatura Brasileira Contemporânea, No. 4, jan./jun. 2016, pp.323-326. 
NEUTRALIZANDO 0 ARGUMENTO DA QUALIDADE: RESULTADOS PRELIMINARES...

COUTINHO, A. "Some Considerations on the Problem of Philosophy in Brazil". In: Philosophy and Phenomenological Research, Papers and Discussions of the First Inter-American Conference of Philosophy, Vol. 4, No. 2, 1943, pp.186-193.

CORRELL, J. et al. "Across the Thin Blue Line: Police Officers and Racial Bias in the Decision to Shoot". In: Journal of Personality and Social Psychology, Vol. 92, No. 6, 2007, pp.1006-1023.

COSTA, R. "Estrangeiros em própria terra: uma reflexão sobre Filosofia na América Latina a partir da questãoindígena". In: Problemata: Revista Internacional de Filosofia. No. Especial, 2015, pp.151-171.

CRUZ COSTA, J. "Sobre o Trabalho Teórico: Entrevista com João Cruz Costa”.In: Revista Trans/Form/Ação, Vol. 2, 1975, pp.87-94.

DI BELLA, L., MILES, E. \& SAUL, J. "Philosophers Explicitly Associate Philosophy with Malesness: An Examination of Implicit and Explicit Gender Stereotypes in Philosophy". In: BROWNSTEIN, M. \& SAUL, J. Implicit Bias and Philosophy, Volume 1: Metaphysics and Epistemology.Oxford: Oxford University Press, 2016, pp.283-308.

FERREIRA, D. "Profissão: Filósofo. Um estudo sobre a Profissionalização da Filosofia no Brasil”. In: Focus, Colóquio Saber e Poder, No. 10, 2008, pp.1-13.

FOUCAULT, M. Microfísica do Poder. Rio de Janeiro: Graal, 1979. 
FRICKER, M. Epistemic Injustice: Power and the Ethics of Knowing. Oxford: Oxford University Press, 2010.

FRICKER, M. "Rational Authority and Social Power: Towards a Truly Social Epistemology". In: GOLDMAN, A. \& WHITCOMB, D. Social Epistemology: Essential Readings. New York: Oxford University Press, 2011.

GALLAS, D. "Rebuilding lives after Brazil's 'worst mining accident"'.BBC NEWS [http://www.bbc.com/news/business34849083], Nov. 2015.

GAWRONSKI, B. \& PAYNE, B. "A History of Implicit Social Cognition: Where is it coming from? Where is it now? Where is it going?". In: GAWRONSKI, B. \& PAYNE, B. Handbook of Implicit Social Cognition: Measurement, Theory and Applications. New York: The Guilford Press, 2010, pp.1-15.

GRACIE, R. "Hall of Fame: Interview with Royce Gracie". In: Ultimate Fighting Championship Classics, UFC 1: Where it All Began (DVD). United States, 1994.

GROSFOGUEL, R. "The Structure of Knowledge in Westernized Universities: Epistemic Racism/Sexism and the Four Genocides/ Epistemicides of the Long $16^{\text {th }}$ Century". In: Human Architecture: Journal of the Sociology of Self-Knowledge, Vol. 9, No. 1, 2013, pp.73-90.

HASLANGER, S. "Changing the Ideology and Culture of Philosophy: Not by Reason (Alone)". In: Hypatia, Vol. 23, No. 2, Spring 2008, pp.210-223. 
NEUTRALIZANDO 0 ARGUMENTO DA QUALIDADE: RESULTADOS PRELIMINARES...

HEGEL, G. W. Filosofia da História. Brasília: Ed. UnB, 2008.

HOOD, S. "Rock the Boat". 30 $0^{\text {th }}$ Melbourne International Comedy Festival, 2016.

LACOSTE, Y. A Geografia: Isso serve, em primeiro lugar, para fazer a Guerra.Ed. Papirus. Campinas, 2001.

LATOUR, B. “Perspectivism: 'Type'or 'Bomb'?”. In:Anthropology Today (Editorial), Vol. 25, No. 2, Apr. 2009, pp.1-2.

LEE, C. et al. "Bias in Peer Review". In: Journal of the American Society for Information Science and Technology, Vol, 64, No. 1, 2013, pp.2-17.

LÉVI-STRAUSS, C. Mythologiques, Vols. 1-4. Paris:Plon, 1964-1971.

LOMBROZO, T., KNOBE, J. \& NICHOLS, S. Oxford Studies in Experimental Philosophy, Vol. 1. Oxford: Oxford University Press, 2014.

MARGUTTI, P. “Sobre a nossa Tradição Exegética e a Necessidade de uma Reavaliação do Ensino de Filosofia no País”. In: Kriterion, No. 129, jun. 2014a, pp.397-410.

MARGUTTI, P. "A Tarefa Da Filosofia Brasileira: Entrevista Com Paulo Margutti”. In: Outramargem: Revista de Filosofia, No. $1,2^{\circ}$ semestre de 2014 b, pp.6-14.

MIGNOLO, W. "Epistemic Disobedience, Independent Thought and Decolonial Freedom". In: Theory, Culture \& Society, Vol. 26, No. 7-8, 2009, pp.159-181. 
MIGNOLO, W. "Geopolitics of Sensing and Knowing: On (De) Coloniality, Border Thinking and Epistemic Disobedience". In: Postcolonial Studies, Vol. 14, No. 3, 2011a, pp.273-283.

MIGNOLO, W. The Darker Side of Western Modernity: Global Futures,Decolonial Options. London: Duke University Press, $2011 b$.

MOSS-RACUSIN, C. et al. "Science Faculty's Subtle Gender Biases Favor Male Students”. In: PNAS, Vol. 109, No. 41, Oct. 2012, pp.16474-16479.

MURPHY, T. Experimental Philosophy 1935-1965. In: LOMBROZO, T., KNOBE, J. \& NICHOLS, S. Oxford Studies in Experimental Philosophy, Volume 1. Oxford: Oxford University Press, 2014, pp.325-368.

NASCIMENTO, W. \& BOTELHO, D. "O Currículo de Filosofia Brasileiro entre Discursos Coloniais: A Colonialidade e a Educação". In: Revista Sul-Americana de Filosofia e Educação, No 14, mai./out. 2010, pp.66-89.

NUNES, B. O Dorso do Tigre. São Paulo: Perspectiva, 1969.

NUNES, B. "O Animal e o Primitivo: Os Outros de nossa Cultura”. In: História, Ciências, Saúde, Vol.14, Suplemento, dez. 2007, pp.279-290.

ORUKA, H. O. Sage Philosophy: Indigenous Thinkers and the Modern Debate in African Philosophy. Leiden: E. J. Brill, 1990a. 
NEUTRALIZANDO 0 ARGUMENTO DA QUALIDADE: RESULTADOS PRELIMINARES...

ORUKA, H. O. "Cultural Fundamentals in Philosophy". In: Quest: An International African Journal of Philosophy, Vol. 4, No. 2, 1990b, pp.21-37.

ORUKA, H. O. "Sagacity in African Philosophy," In: SEREQUEBERHAN, T. African Philosophy: The Essential Readings. New York: Paragon, 1991.

PARK, P. Africa, Asia and the History of Philosophy: Racism in the Formation of the Philosophical Canon, 1780-1830. Albany: SUNY Press, 2013.

PILGER, J. \& MARTIN, C. War on Democracy (DVD).United Kingdom, 2007.

PIMENTEL, J. E. "As Utopias Disciplinares, Leituras Foucaultianas". In: RevistaIdeação, No. 33, jan./jun. 2016, pp.19-46.

PLUMWOOD, V. Feminism and the Mastery of Nature. London: Routledge, 1997.

PORCHAT, O. "Discurso aos Estudantes de Filosofia da USP sobre a Pesquisa em Filosofia”.In: Fundamento, Vol. 1, No. 1, set./dez. 2010, pp.18-33.

PRESBEY, G. "Sage Philosophy: Criteria that Distinguish it from Ethnophilosophy and make it a Unique Approach within African Philosophy." In: Philosophia Africana, Vol. 10, No. 2, 2007, pp.127-160.

PUNTEL, L. Structure and being: A Theoretical Framework for a Systematic Philosophy. Pennsylvania: The Pennsylvania State University Press, 2008. 
RAMOS, A. "The Politics of Perspectivism". In: Annual Review of Anthropology, Vol. 41, 2012, pp.481-94.

ROUSSEAU, J.-J. Emílio ou da Educação. Ed. Martins Fontes: São Paulo, 2009.

SEABRA, M. "História da Arte e das Ciências Humanas: Palcos para Lutas Linguísticas". Áskesis: Revista dos Discentes do PPGS/UFSCar, Vol. 1, No. 2, jul./dez. 2012, pp.124-139.

SEABRA, M. Metafilosofia: Lutas Simbólicas, Sensibilidade e Sinergia Intelectual, Brasília: Bibliofonte, 2014.

SILVEIRA, G. "A Modernização do Pensar como Violência: O Legado das Missões Francesas da USP e o Caso Jean Maugüé".In: Problemata: RevistaInternacional de Filosofia. No. Especial, 2015, pp.202-221.

VALLS, A. Race and Racism in Modern Philosophy. Ithaca: Cornell University Press, 2005.

VIVEIROS DE CASTRO, E. “Cannibalmetaphysics: Amerindian Perspectivism”. In: Radical Philosophy, Vol. 182, Nov./Dec. 2013, pp.17-28.

WUESNCH, A. "Acerca da Existência de Pensadoras no Brasil e na América Latina".In: Problemata: Revista Internacional de Filosofia, No. Especial, 2015, pp.113-150. 